\title{
Development and initial validation of a new short and simple Health-Related Quality Of Life (HRQL) Questionnaire for Pediatric Rheumatic Diseases (PRD)
}

E Palmisani*1, G Filocamo' ${ }^{1}$, C Saad-Magalhaes ${ }^{1}$, A Consolaro ${ }^{1}$, S MagniManzoni ${ }^{2}$, S Viola ${ }^{1}$, A Pistorio ${ }^{1}$, N Ruperto ${ }^{1}$, D Tani ${ }^{1}$, S Serpico ${ }^{1}$, A Martini ${ }^{1}$ and A Ravelli ${ }^{1}$

Address: ${ }^{1}$ IRCCS G Gaslini, Genova, Italy and ${ }^{2}$ IRCCS Pol San Matteo, Pavia, Italy

* Corresponding author

from 15th Paediatric Rheumatology European Society (PreS) Congress

London, UK. 14-17 September 2008

Published: 15 September 2008

Pediatric Rheumatology 2008, 6(Suppl I):PI07 doi:I0.II86/I546-0096-6-SI-PI07

This abstract is available from: http://www.ped-rheum.com/content/6/SI/PI07

(c) 2008 Palmisani et al; licensee BioMed Central Ltd.

\section{Objective}

To develop a new short and simple measure for assessment of HRQL in PRD and provide preliminary evidence of its validity in JIA.

\section{Methods}

The Pediatric Rheumatology Quality of Life (PRQL) includes 10 questions, each scored from 0 (normal) to 3 (worst). Score range is $0-30$. The PRQL contains two subscales, each composed of 5 questions (score range 0-15), that assess physical (PhH) and psychosocial (PsH) health. Validation of PRQL included evaluation of feasibility, face and content validity. Construct validity was assessed by calculating Spearman's correlation with JIA outcome measures in 723 visits (403 patients) made between 2007 and 2008. Construct validity of PRQL was compared with that of Child Health Questionnaire (CHQ) by assessing the same correlations of in a historical sample of 501 visits (448 patients) made between 2002 and 2006 who had CHQ completed.

\section{Results}

All completers reported that PRQL was easy to understand and fill. Completion time was $<5$ minutes. Table 1 reports Spearman's correlations for PRQL and CHQ.

\section{Conclusion}

The PRQL proved feasible and showed good face and content validity. Construct validity was comparable to that of an established pediatric HRQL measure (the CHQ). 
Table I: Spearman's correlations for PRQL and CHQ

\begin{tabular}{lllllll}
\hline & Parent global & Parent pain & Functional ability & MD global & Restricted joints & Active joints \\
\hline PRQL - PhH & 0.65 & 0.68 & $0.57^{*}$ & 0.39 & 0.35 & 0.34 \\
PsH & 0.38 & 0.40 & $0.30^{*}$ & 0.19 & 0.18 & 0.16 \\
CHQ - PhS & -0.61 & -0.63 & $-0.51^{* *}$ & -0.45 & -0.35 & -0.43 \\
PsS & -0.28 & -0.25 & $-0.26^{* *}$ & -0.13 & -0.14 & -0.18 \\
\hline
\end{tabular}

*JAFS; ** CHAQ

Publish with Biomed Central and every scientist can read your work free of charge

"BioMed Central will be the most significant development for disseminating the results of biomedical research in our lifetime. " Sir Paul Nurse, Cancer Research UK

Your research papers will be:

- available free of charge to the entire biomedical community

- peer reviewed and published immediately upon acceptance

- cited in PubMed and archived on PubMed Central

- yours - you keep the copyright 